This Accepted Author Manuscript is copyrighted and published by Elsevier. It is posted here by agreement between Elsevier and University of Brasilia. Changes resulting from the publishing process - such as editing, corrections, structural formatting, and other quality control mechanisms - may not be reflected in this version of the text. The definitive version of the text was subsequently published in [Theriogenology, Volume 61, Issue 6, 15 April 2004, Pages 11011114, Pages 461-472, doi:10.1016/j.theriogenology.2003.06.004].You may download, copy and otherwise use the AAM for non-commercial purposes provided that your license is limited by the following restrictions:

(1) You may use this AAM for non-commercial purposes only under the terms of the CC-BY-NCND license.

(2) The integrity of the work and identification of the author, copyright owner, and publisher must be preserved in any copy.

(3) You must attribute this AAM in the following format: [agreed attribution language, including link to CC BY-NC-ND license + Digital Object Identifier link to the published journal article on Elsevier's ScienceDirect ${ }^{\circledR}$ platform].

Este Manuscrito do Autor Aceito para Publicação (AAM) é protegido por direitos autorais e publicado pela Elsevier. Ele esta disponível neste Repositório, por acordo entre a Elsevier e a Universidade de Brasília. As alterações decorrentes do processo de publicação - como a edição, correção, formatação estrutural, e outros mecanismos de controle de qualidade - não estão refletidas nesta versão do texto. A versão definitiva do texto foi posteriormente publicado em [Theriogenology, Volume 61, INúmero 6, 15 Abril de 2004, Páginas 1101-1114, doi:10.1016/j.theriogenology.2003.06.004]. Você pode baixar, copiar e utilizar de outra forma o AAM para fins não comerciais, desde que sua licença seja limitada pelas seguintes restrições:

(1) Você pode usar este AAM para fins não comerciais apenas sob os termos da licença CC- BYNC-ND.

(2) A integridade do trabalho e identificação do autor, detentor dos direitos autorais e editor deve ser preservado em qualquer cópia.

(3) Tem de atribuir este AAM no seguinte formato: [acordo na linguagem atribuída, incluindo o link para CC BY-NC-ND licença Digital + DOI do artigo publicado na revista Elsevier ScienceDirect ${ }^{\circledR}$ da plataforma]. 


\title{
Effect of different cryoprotectants on the structural preservation of follicles in frozen zebu bovine (Bos indicus) ovarian tissue
}

\author{
Carolina M Lucci \\ Mirella A Kacinskis \\ Luiz Henrique R Lopes \\ Rodolfo Rumpf \\ Sônia N Báoa
}

\begin{abstract}
Cryopreservation of ovarian tissue is a new and promising technique for germ-line storage. The objective of this study was to evaluate the effect of four cryoprotectants (at two concentrations each) on the preservation of zebu bovine preantral follicles after ovarian cryostorage. Strips of ovarian cortex were cryopreserved using glycerol (GLY; 10 or 20\%), ethylene glycol (EG), propanediol (PROH) or dimethylsulphoxide (DMSO; 1.5 or $3 \mathrm{M}$ ). In addition, a toxicity test was performed for each cryoprotectant by exposing the ovarian tissue to them without freezing. Tissues were analyzed by histology and transmission electron microscopy. Ovarian tissue frozen in either concentration of DMSO or PROH or in $10 \%$ GLY retained a higher percentage of morphologically normal follicles (73-88\%) than tissue frozen in $20 \% \mathrm{GLY}$ or in either concentration of EG (16-52\%). In the toxicity test, exposure of tissues to DMSO, PROH or GLY resulted in higher percentages of normal follicles (80-97\%) than exposure to EG $(49 \%)$. Electron microscopy revealed damage to the ultrastructure of follicles frozen in $10 \%$ GLY, while follicles cryopreserved in DMSO and PROH at either concentration exhibited normal ultrastructure. In conclusion, DMSO and PROH were the most effective cryoprotectants for zebu ovarian tissue, preserving the structural integrity of somatic and reproductive cells within the ovary.
\end{abstract}

Keywords: Cryopreservation; Ovarian tissue; Preantral follicles; Cryoprotectants; Bovine

\section{Introduction}

The ability to cryopreserve female gametes has important applications for clinical treatment of infertility, as well as for conservation of endangered species and economically important breeds. Oocyte cryopreservation has been frequently attempted, but consistently with poor results [1] and [2]. There are several explanations for the difficulty of storing GV and MII oocytes at low temperatures. First, oocytes are large cells (always a disadvantage for cryopreservation) with little capacity for repairing damage. Additionally, cooling and exposure to cryoprotectants may cause premature release of cortical granules and subsequent zona pellucida hardening. Furthermore, the meiotic spindle is temperature-sensitive and depolymerises during cooling. Although this process is reversible, there is concern that chromosomes may become displaced and cause aneuploidy [1] and [2].

An alternative strategy for storing female germ cells is cryopreservation of ovarian tissue. This method enables the storage of large numbers of oocytes (within primordial 
follicles). Unlike fully-grown oocytes, oocytes in primordial follicles tolerate cryopreservation very well. Several characteristics make them less vulnerable to cryoinjury. The most important of these characteristics are:

(a) the small size of the oocyte and its support cells;

(b) the oocyte's low metabolic rate;

(c) the absence of zona pellucida and peripheral cortical granules; and

(d) the small amount of cold-sensitive intracytoplasmic lipid.

Furthermore, these immature oocytes are arrested in prophase and theoretically carry a lower risk of cytogenetic errors. Furthermore, primordial follicles have time to repair sub-lethal damage to organelles and other structures during their prolonged growth phase [1] and [3]. Cryopreservation of ovarian tissue offers even more advantages over the cryopreservation of unfertilized oocytes, because ovarian tissue collection is not dependent on age or the stage of the estrous cycle and can even be applied to animals that die unexpectedly [3].

Cryopreservation of ovarian tissue proved to be effective for a wide range of species including mice [4], [5] and [6], sheep [7], [8] and [9], cattle [10], humans [11] and [12] and marmosets [13]. In general, viable tissue has been obtained after ovarian cryostorage in the cryoprotectants dimethylsulphoxide (DMSO), ethylene glycol (EG), and propanediol (PROH), while glycerol (GLY) appeared to be slightly less effective [4] and [12]. However, it is important to note that the response to a given cryoprotectant can vary greatly among species and from one cell type to another [14] and [15]. In fact, studies comparing the effects of various cryoprotective agents on ovarian tissue preservation have been performed for mice [4] and humans [12]. These studies are important in determining the best cryoprotectant to be used for each species in a given condition. The only study concerning cryopreservation of bovine ovarian tissue used DMSO as a cryoprotectant [10]. A comparative study to evaluate the effect of different cryoprotectants on the preservation of follicles within bovine ovarian tissue has not been reported.

The objective of the present study was to evaluate the effect of four cryoprotectants (GLY, $E G, P R O H$, and DMSO) on the preservation of zebu preantral follicles after ovarian frozen storage. In addition, a toxicity test was performed for each cryoprotectant. 


\section{Materials and methods}

\subsection{Source of ovaries and tissue preparation}

Three ovaries (from three different animals) from zebu (Nelore) cows were used. The ovaries were collected at a local abbatoir and transported to the laboratory at $32-34{ }^{\circ} \mathrm{C}$ within 1-3 h. In the laboratory, ovaries were trimmed and rinsed with $70 \%$ ethanol and sterile saline solution, prior to removal of the outer cortex. Then, 13 small strips of ovarian cortex $(\sim)$ were taken from each ovary. One piece from each ovary was chosen at random to be the control and immediately fixed. The other 12 pieces were randomly distributed into 12 treatment groups.

\subsection{Experimental protocol}

Four cryoprotectants were compared in this study: GLY (Gibco-BRL, Life Technologies, Grand Island, NY, USA), EG (Merck, Darmstadt, Germany), PROH (Aldrich Chemical Co., Inc. Milwaukee, WI, USA), and DMSO (Sigma Chemical Co., St. Louis, MO, USA). Each cryoprotectant was prepared at two different concentrations: 10 and 20\% for GLY and 1.5 and $3 \mathrm{M}$ for EG, PROH and DMSO. All cryoprotectant solutions were prepared in Medium 199 (with HEPES and Hank's salts; Gibco-BRL) containing 0.4\% BSA (Sigma) and $0.1 \mathrm{M}$ sucrose (Sigma), i.e. modified Medium 199 (M 199+).

The toxicity of each cryoprotectant was tested by exposing the ovarian tissue to each cryoprotectant at the low concentration, without freezing. Cryopreservation was performed using the four cryoprotectants at both concentrations. A chart of the experimental treatments is presented in Fig. 1. 


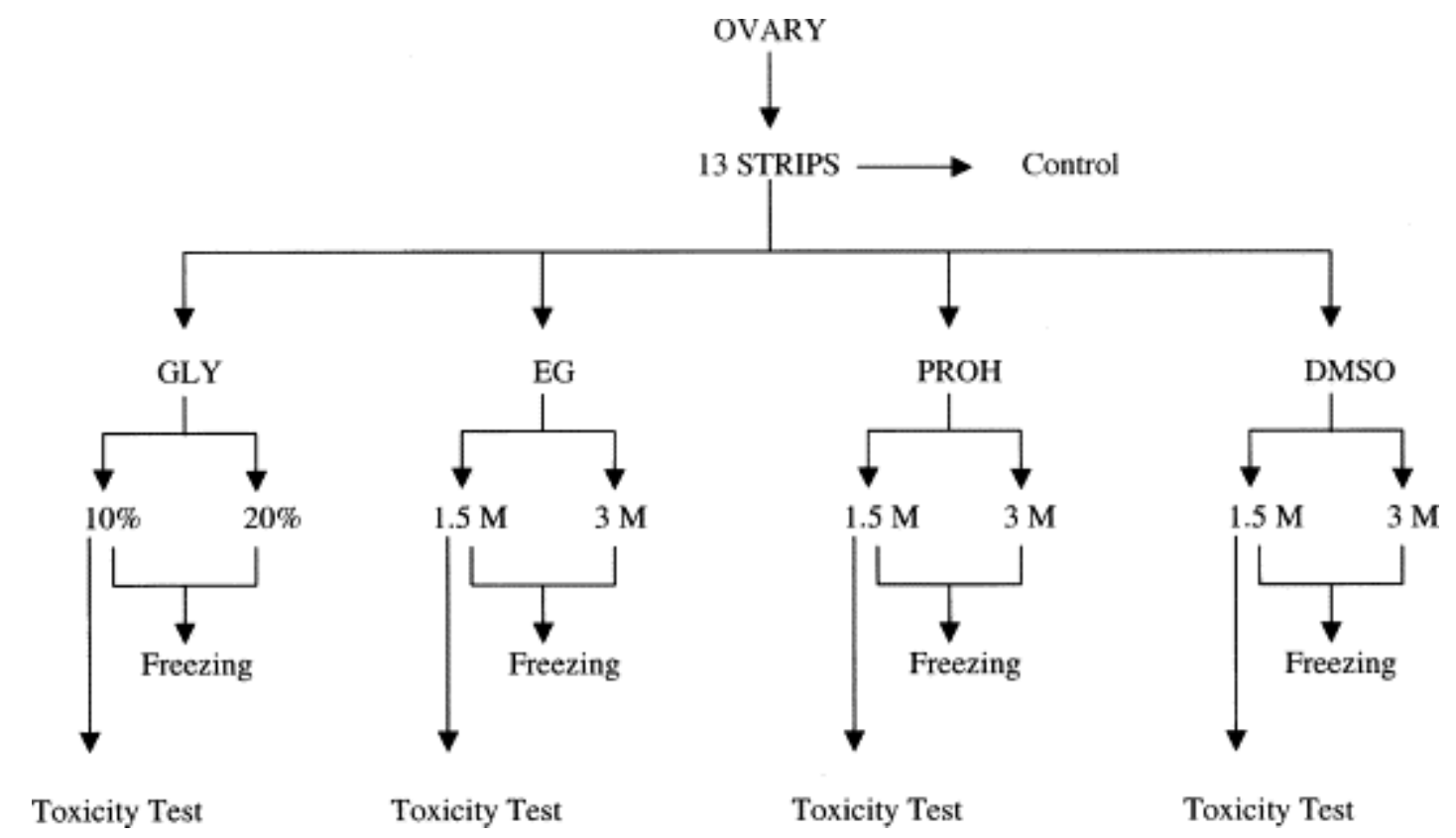

Fig. 1. Experimental protocol to test the effect of different cryoprotectants on the cryopreservation of zebu cow ovarian tissue

\subsection{Toxicity test, freezing and thawing}

To evaluate the toxicity of the cryoprotectants to preantral follicles, ovarian strips were exposed to either $10 \% \mathrm{GLY}$ or $1.5 \mathrm{M} \mathrm{EG}, \mathrm{PROH}$ or DMSO at $20^{\circ} \mathrm{C}$. After an equilibration time of $20 \mathrm{~min}$, the cryoprotectant was removed by washing the samples three times $(5 \mathrm{~min}$ each), twice in M 199+ containing decreasing concentrations of the cryoprotectants ( 0.5 and 0.25 times the concentration used in the cryopreservation), and once in pure M 199+.

For cryopreservation, pieces of ovarian cortex were placed into $1.2 \mathrm{ml}$ cryogenic vials (Nalgene, Rochester, NY, USA; one piece per vial) containing $1 \mathrm{ml}$ of cryoprotectant solution, and frozen using a programmable freezer (CryoLogic CL-863, Victoria, Australia). Vials were equilibrated at $20^{\circ} \mathrm{C}$ for $20 \mathrm{~min}$ and then cooled from $20^{\circ} \mathrm{C}$ at $1{ }^{\circ} \mathrm{C} / \mathrm{min}$ to $-7{ }^{\circ} \mathrm{C}$ and held at this temperature for $10 \mathrm{~min}$. At this point, samples were manually seeded and then cooled at $0.3{ }^{\circ} \mathrm{C} / \mathrm{min}$ to $-30^{\circ} \mathrm{C}$. The vials were then plunged into liquid nitrogen $\left(-196^{\circ} \mathrm{C}\right)$ and stored for 1 week. Samples were thawed by warming the cryovials in air for $30 \mathrm{~s}$, followed by immersion in water at $38{ }^{\circ} \mathrm{C}$ until the ice melted. Tissues were washed to remove the cryoprotectant, as described for the toxicity test.

\subsection{Histological evaluation}

Samples from the three tissue groups (control, toxicity test, and cryopreserved) were processed for histology to evaluate the morphology of preantral follicles. A small piece of each 
ovarian fragment was removed for subsequent electron microscopy evaluation and the remainder was fixed in Carnoy fixative for $4 \mathrm{~h}$. Samples were then dehydrated in ethanol, clarified with xylene, embedded in paraffin wax and sectioned at $5 \mu \mathrm{m}$ thickness. The sections were stained with hematoxylin and eosin (HE), and examined under a Zeiss Axiophot light microscope (Oberkochen, Germany).

Preantral follicles were classified according to their developmental stage as primordial (one layer of flattened or flattened-cuboidal granulosa cells around the oocyte), primary (one layer of cuboidal granulosa cells around the oocyte) and secondary follicles (two or more layers of cuboidal granulosa cells around the oocyte). Follicular quality was evaluated at the same time and follicles were classified as normal or degenerate, according to their morphological appearance. Follicles were classified as degenerate if they had one or more of the following aspects: condensed oocyte nucleus; shrunken oocyte; non-homogeneous ooplasm; pycnotic bodies in the granulosa cells; or low cellular density.

\subsection{Ultrastructural evaluation}

Tissue samples from the control group and the cryopreserved group were processed for transmission electron microscopy (TEM). In brief, small pieces of ovarian cortex were fixed in $2 \%$ paraformaldehyde, $2.5 \%$ glutaraldehyde and $0.1 \mathrm{M}$ sodium cacodylate buffer $(\mathrm{pH} 7.2)$ for $3 \mathrm{~h}$ at room temperature. After being washed with sodium cacodylate buffer, the ovarian pieces were postfixed in a solution containing $1 \%$ osmium tetroxide, $0.8 \%$ potassium ferricyanide and $5 \mathrm{mM}$ calcium chloride in $0.1 \mathrm{M}$ sodium cacodylate buffer. Subsequently, the samples were dehydrated in acetone and embedded in Spurr. Semi-thin sections $(3 \mu \mathrm{m})$ were stained with Toluidine Blue. Thin sections $(70 \mathrm{~nm})$ were stained with uranyl acetate and lead citrate, and examined in a Jeol JEM $100 \mathrm{C}$ transmission electron microscope (Jeol, Tokyo, Japan). Only preantral follicles with normal morphology at semi-thin sections were evaluated for ultrastructural organization (at least five follicles per treatment). All electron microscopy reagents were purchased from Electron Microscopy Sciences (Ft. Washington, PA, USA).

\subsection{Statistical analysis}

Data were arcsine-transformed and analyzed by ANOVA and Fisher's protected LSD test (StatView for Windows, SAS Institute Inc., Cary, NC, USA). Values were considered 
statistically significant when $\mathrm{P}<0.05$ and are presented as mean \pm S.E.M. calculated from three replicates.

\section{Results}

A total of 2036 preantral follicles ( $157 \pm 22$ per treatment, $52 \pm 8$ per ovarian piece) were analyzed. The percentages of morphologically normal follicles in the control, toxicity test and cryopreservation treatments are presented in Table 1. A very low rate of degeneration was observed in non-treated ovarian tissue (control, 3.1\%). When compared to the control, nonfrozen ovarian tissue exposed to 1.5 M DMSO or $\mathrm{PROH}$ had similar percentages of morphologically normal follicles, while those exposed to $10 \%$ GLY or 1.5 M EG had significantly less normal follicles.

Table 1.

Mean ( \pm S.E.M.) percentages of morphologically normal follicles in pieces of ovarian tissue submitted to different treatments: control (untreated), toxicity test (exposed to the low concentration of the cryoprotectants without freezing), and frozen (cryopreserved in different cryoprotectants at low $(10 \%$ or $1.5 \mathrm{M})$ or high $(20 \%$ or $3 \mathrm{M})$ concentration)

\begin{tabular}{|c|c|c|c|c|}
\hline \multirow[t]{2}{*}{ Treatment } & \multicolumn{4}{|l|}{ Cryoprotectants } \\
\hline & Glycerol & Ethylene glycol & Propanediol & DMSO \\
\hline Control & $96.9 \pm 2.6$ & $96.9 \pm 2.6$ & $96.9 \pm 2.6$ & $96.9 \pm 2.6$ \\
\hline Toxicity test & $80.1 \pm 9.1^{\circ} \mathrm{aA}$ & $49.2 \pm 2.6^{\cdots . \mathrm{bA}}$ & $97.2 \pm 2.8^{\mathrm{eA}}$ & $97.3 \pm 1.4^{\mathrm{CA}}$ \\
\hline Frozen-low concentration & $77.0 \pm 6.5^{\circ} \cdot \mathrm{aA}$ & $52.5 \pm 14.2^{* *, \mathrm{bA}}$ & $72.9 \pm 2.4^{*, \mathrm{AB}}$ & $73.9 \pm 6.3^{*}, \mathrm{aB}$ \\
\hline Frozen-high concentration & $16.2 \pm 8.8^{* *}, \mathrm{aB}$ & $32.8 \pm 6.2^{* *}+A$ & $81.7 \pm 3.5^{*}, \mathrm{hB}$ & $88.4 \pm 2.5^{\mathrm{bAB}}$ \\
\hline
\end{tabular}

Values with different superscripts $(a, b, c)$ differ within row $(P<0: 05$ for the low concentration, $P<0: 01$ for the toxicity test, and $P<0: 0001$ for the high concentration).

Values with different superscripts $(A, B)$ differ within column $(P<0: 01)$.

$* \mathrm{P}<0: 05$, differ from the control.

$* * \mathrm{P}<0: 001$, differ from the control.

When ovarian tissue was frozen in low concentrations of cryoprotectants, all treatments had significantly lower percentages of normal follicles than the control (Table 1). Moreover, the percentage of normal follicles in ovarian pieces cryopreserved in 1.5 M EG was significantly lower than in the other cryoprotectants at low concentration. When tissue was frozen in high concentrations of cryoprotectants, the percentage of normal follicles observed in ovarian pieces cryopreserved in DMSO was similar to the control, while the other cryoprotectants had a significantly lower percentage. Moreover, GLY and EG had significantly lower percentages of normal follicles than DMSO and PROH.

During histological analysis, morphologically normal follicles were characterized by a round or oval oocyte, presenting a well-delimited nucleus with uncondensed chromatin, 
surrounded by healthy granulosa cells closely juxtaposed to the oocyte (Fig. 2A). Among morphologically abnormal follicles, two types of degeneration could be distinguished. The most predominant type was characterized by picnosis of the oocyte nucleus (Fig. 2B); this observed with great frequency in ovarian tissue exposed to or cryopreserved in EG, and with lower frequency in tissue exposed to or cryopreserved in 10\% GLY, cryopreserved in 1.5 and 3 $\mathrm{M} P R O H$ and $1.5 \mathrm{M}$ DMSO. This kind of degeneration was also observed in the control and in tissue exposed to $\mathrm{PROH}$ and DMSO and cryopreserved in $3 \mathrm{M}$ DMSO, although at very low rates. The other type of degeneration was characterized by shrinkage of the oocyte and granulosa cells, detachment of the follicle from the surrounding stroma, loss of contact between oocyte and granulosa cells, and picnosis of granulosa cells (Fig. 2C). This type of degeneration was observed most often in preantral follicles from ovarian tissue cryopreserved in $20 \%$ GLY. In general, the developmental stage of the follicles did not affect their susceptibility to degeneration. In all treatments, there was no difference between the degeneration rates of primordial, primary and secondary follicles.
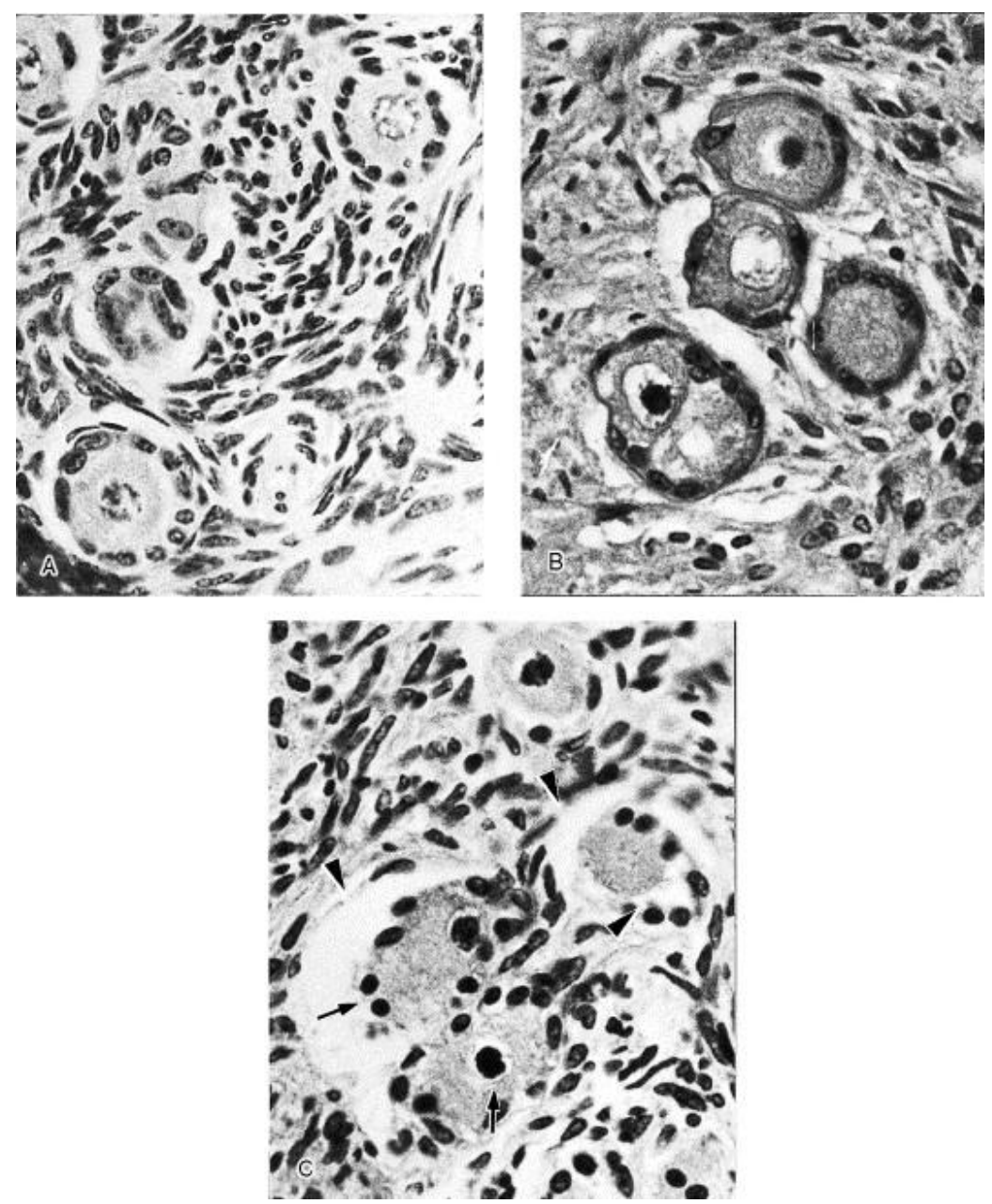

Fig. 2. Histological sections of ovarian tissue stained with HE. (A) Ovarian tissue exposed to 1.5 M DMSO with morphologically normal follicles. (B) Ovarian tissue cryopreserved in $1.5 \mathrm{M}$ EG with abnormal 
follicles; the predominant sign of degeneration was picnosis of the oocyte nucleus. (C) Ovarian tissue cryopreserved in $20 \%$ GLY with degenerate follicles; note the detachment of follicles from the surrounding stroma and of oocytes from granulosa cells (arrowheads), as well as the picnosis of oocyte and granulosa cells nuclei (arrows). Magnification: 600x.

When viewed with the electron microscope, follicles from the control group (Fig. 3) had oocytes with a large nucleus well delimited by the nuclear envelope. Numerous mitochondria, a few cisternae of smooth endoplasmic reticulum and Golgi apparatus, and a few vesicles were evenly distributed throughout a homogeneous cytoplasm. Granulosa cells had many elongated mitochondria, abundant smooth and rough endoplasmic reticulum and Golgi apparatus, and were tightly connected to the oocyte. Follicles cryopreserved in $1.5 \mathrm{M}$ DMSO (Fig. 4A) had ultrastructure very similar to the control, with no evident alterations that could be attributed to cryopreservation. The oocytes of follicles cryopreserved in 3 M DMSO (Fig. 4B) and in 1.5 or $3 \mathrm{M} \mathrm{PROH} \mathrm{(Fig.} \mathrm{5A} \mathrm{and} \mathrm{B)} \mathrm{also} \mathrm{displayed} \mathrm{normal} \mathrm{ultrastructure,} \mathrm{although}$ some granulosa cells had loss of cytoplasm content. On the other hand, the TEM analysis of follicles cryopreserved in $10 \%$ GLY revealed damage to organelles and disorganization of the cytoplasm structure, both in granulosa cells (Fig. 6A) and in the oocyte (Fig. 6B). In the oocyte, organelles were grouped in small areas, instead of being evenly distributed throughout the cytoplasm. Most mitochondria lost their cristae and some of them had a granulated matrix. The ooplasm had an abnormal appearance, with clusters of cytoplasmic material and large empty spaces. Vacuolization of oocyte and granulosa cells cytoplasm was common. Ultrastructural analysis was not performed in ovarian tissue cryopreserved in 1.5 and 3 M EG and $20 \% \mathrm{GLY}$, since these treatments had very high degeneration rates during the histological evaluation and had already been eliminated as possibilities for preservation of zebu preantral follicles. 


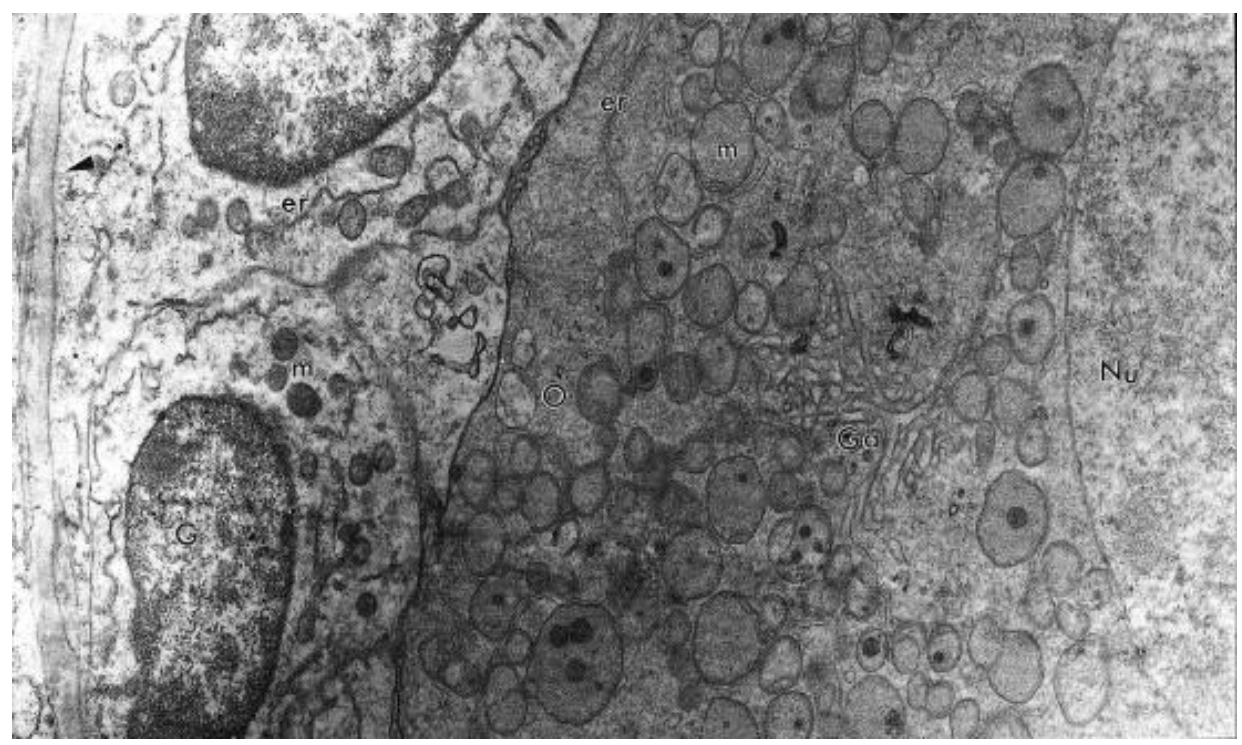

Fig. 3. Electron micrograph of a non-treated follicle (control). Arrowhead shows the basement membrane. O: oocyte; G: granulosa cell; $\mathrm{Nu}$ : oocyte nucleus; m: mitochondria; er: endoplasmic reticulum, Ga: Golgi apparatus. Magnification: 7500x.
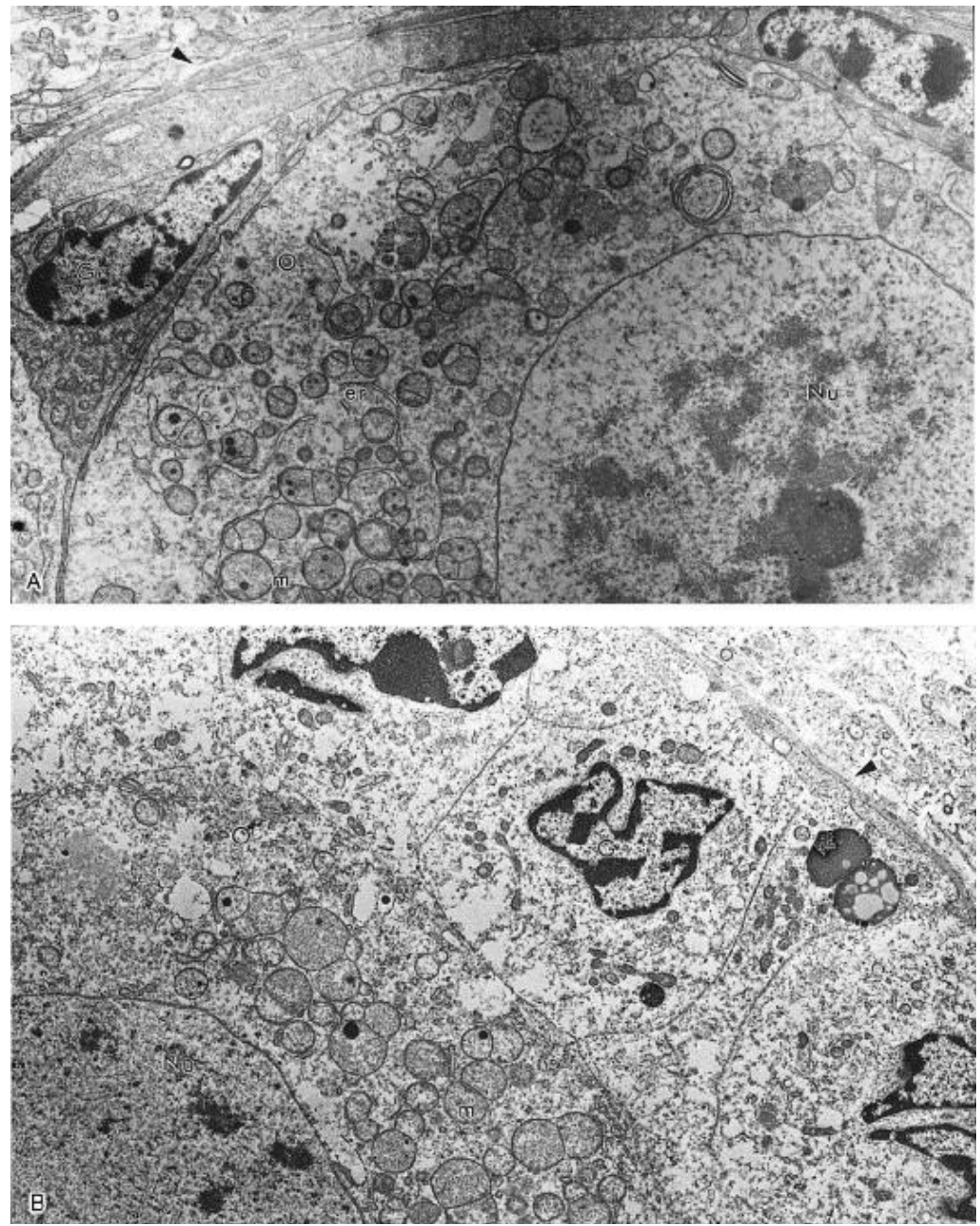

Fig. 4. Electron micrographs of follicles cryopreserved in $1.5 \mathrm{M}(\mathrm{A})$ and $3 \mathrm{M}(\mathrm{B}) \mathrm{DMSO}$. Note the normal ultrastructure of the oocyte and granulosa cell in $(A)$, and the loss of some cytoplasm content of granulosa cells in (B). Arrowhead shows the basement membrane. O: oocyte; G: granulosa cell; $\mathrm{Nu}$ : oocyte nucleus; m: mitochondria; er: endoplasmic reticulum. Magnification: (A) 4700x and (B) 5800x 

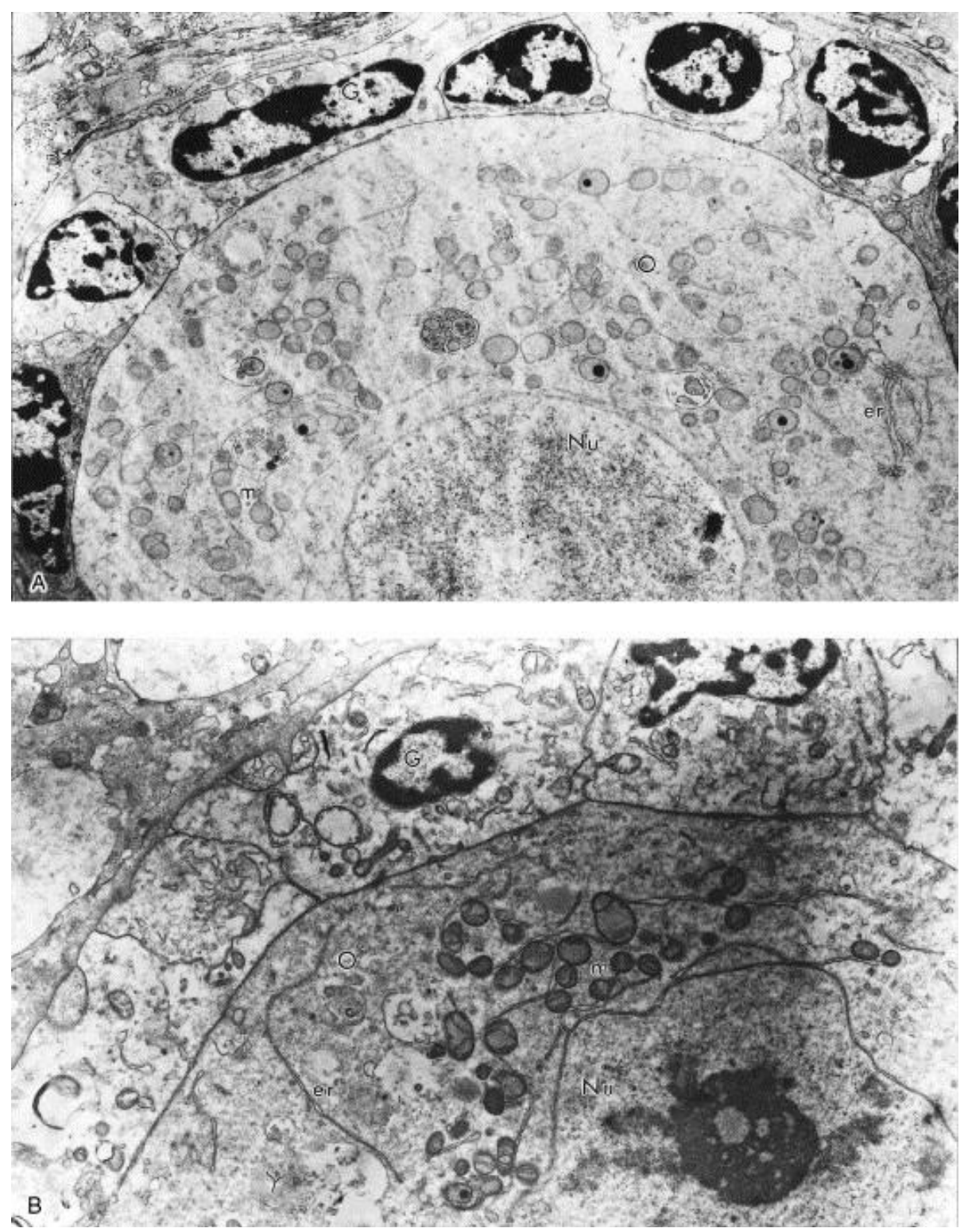

Fig. 5. Electron micrographs of follicles cryopreserved in $1.5 \mathrm{M}(\mathrm{A})$ and $3 \mathrm{M}$ (B) PROH. In (B) granulosa cells have lost some of their cytoplasm. O: oocyte; G: granulosa cell; $\mathrm{Nu}$ : oocyte nucleus; $\mathrm{m}$ : mitochondria; er: endoplasmic reticulum. Magnification: (A) 4700x and (B) 5800x. 

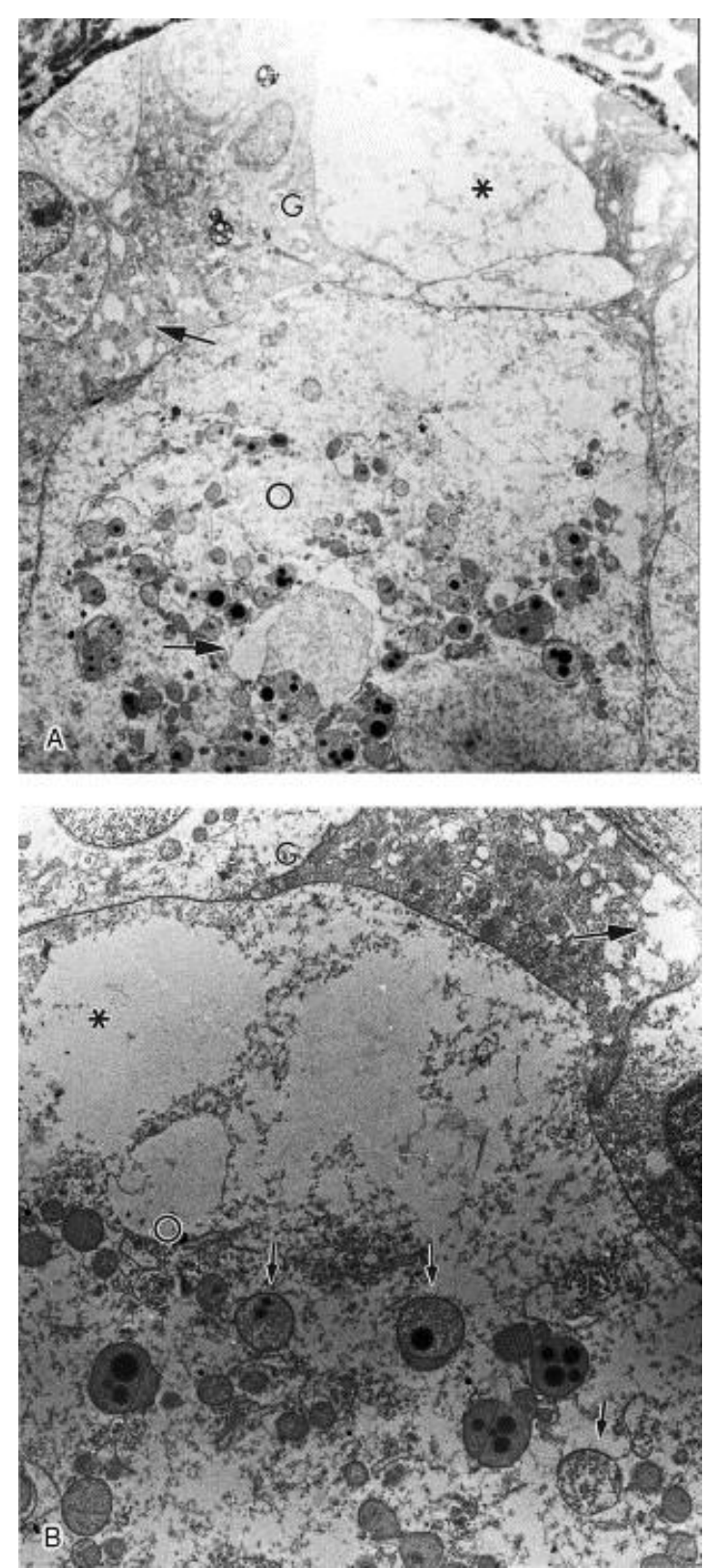

Fig. 6. Electron micrographs of follicles cryopreserved in 10\% GLY. (A) An overview of a damaged follicle with loss of cytoplasmic content of granulosa cells $\left({ }^{*}\right)$ (magnification: 2050x). (B) Detail of the oocyte, with the abnormal appearance of the ooplasm, with large empty spaces $\left({ }^{*}\right)$, and mitochondria with no cristae and granulated matrix (small arrows) (magnification: 4500x). Note the coagulated aspect of the ooplasm and the vacuolization of oocyte and granulosa cells (big arrows). O: oocyte; G: granulosa cell.

\section{Discussion}

The present study was the first to compare the effect of different cryoprotectants on cryopreservation of bovine ovarian tissue. Similar comparative studies were only performed in ovarian tissue from humans [12] and mice [4], and considered only the effects of different cryoprotectants on preservation of preantral follicles. In the present study, bovine ovarian tissue was better preserved in DMSO or PROH than in GLY or EG. 
In the present study, the worst results were obtained when EG was used as cryoprotectant. The mere exposure to EG greatly reduced the percentage of morphologically normal follicles (from 96.9 to $49.2 \%$ ). The cryopreservation of ovarian tissue in $1.5 \mathrm{M}$ EG resulted in percentages of normal follicles (52.5\%) consistent with the toxicity test, and preservation in $3 \mathrm{M}$ EG resulted in even lower percentages of normal follicles (32.8\%). It appears that the damage to the follicles observed using this cryoprotectant was caused by a toxic effect of the EG and not to the cryopreservation process. In previous studies, EG was nontoxic to human [16] and bovine [17] and [18] embryos. Moreover, good results were observed when EG was used to cryopreserve murine ovarian tissue, with $88 \%$ of follicles remaining morphologically normal after freezing/thawing [4]. In humans, the percentage of follicle survival in ovarian tissue after freezing in EG and grafting into SCID mice was 84\% [12]. Strict comparisons between our results and those of others are not possible, due to differences in cell types, species and cryopreservation protocols. It is noteworthy that the ability of cryoprotectants to permeate cell membranes varies; this affects the amount of cryoprotectant that will permeate into or out of the cell. Therefore, the interval that cells are exposed to cryoprotectants is of critical importance, and may dramatically affect toxicity [19]. Due to its lower molecular weight, EG has a higher permeability than DMSO, PROH and GLY [20]; this was probably why EG was the most toxic cryoprotectant in the present study. In mice, Candy et al. [4] observed that ovaries exposed to EG for $60 \mathrm{~min}$ before freezing contained fewer normal follicles, and suggested that this cryoprotectant was toxic when the tissue is exposed to it for prolonged periods before cooling. In our study, ovarian tissue was exposed to the cryoprotectants for only $20 \mathrm{~min}$; perhaps bovine follicles are more sensitive to the toxic effects of EG than follicles from other species. Clearly, a 20-min equilibration period was not necessarily optimal for all cryoprotectants; in future studies this period could be reduced for EG.

In the present study, the toxicity test for GLY resulted in $80.1 \%$ normal follicle, indicating that GLY is relatively nontoxic to zebu preantral follicles. However, this result may be due to the low permeability of GLY, which makes this cryoprotectant to enter the cells very slowly, and thus, after $20 \mathrm{~min}$, the amount of GLY inside the follicular cells was not high enough to be toxic. The percentage of morphologically normal follicles after cryopreservation in $10 \%$ GLY was $77 \%$ in histological sections. However, the electron microscopy analysis revealed that those apparently normal follicles had abnormal ultrastructure. Changes observed in the fine structure of the cytoplasm, mainly empty areas with no membranes surrounding them, were likely due to crystallization, and can be attributed to limited permeability of GLY into the tissue. Similar damage to the ultrastructure was observed in glycerol-frozen ovine 
embryos [21]. Both in our study and in that of Cocero et al. [21], TEM provided a more comprehensive assessment of the process, since important abnormalities could be found in cells that appeared intact under light microscopy. The damage to organelles, observable only by ultrastructural analysis, may be the cause of failure in further development of apparently normal cells. When $20 \%$ GLY was used to cryopreserve bovine ovarian tissue in the present study, the percentage of normal follicles was drastically reduced to $16.2 \%$. Moreover, this very low rate of normal follicles was associated with morphological changes, such as severe cell shrinkage and detachment of the follicle from the surrounding stroma, observed exclusively in this treatment. High concentrations of this cryoprotectant apparently promote high degrees of dehydration and thus excessive and deleterious osmotic stress. Similarly, low percentages of normal follicles were also reported when mouse (28\% [4]) and human (10\% [12]) ovaries were cryopreserved in GLY. Although it is still routinely used for semen storage and has the virtue of being relatively nontoxic [1], GLY appears to be less effective than other cryoprotectants in preserving other cell types (e.g. ovarian tissue [4] and [12], embryos [21]), and has been progressively superseded by them.

Both DMSO and PROH provided good results when ovarian tissue was cryopreserved in either concentration, with high percentages of morphologically normal follicles (74-88\%). Similar percentages of normal follicles were observed in human and mouse ovarian tissue (81 and $82 \%$, respectively [4] and [11]) cryopreserved with $1.5 \mathrm{M} \mathrm{DMSO}$ or $\mathrm{PROH}$. It is worth noting that DMSO is the most widely used cryoprotectant for ovarian tissue cryopreservation, and usually produces good results. In sheep, cortical grafts returned to the orthotopic site (after frozen storage using DMSO) regained estrous cycles and fertility [7]. Additionally, oocyte-granulosa cell complexes isolated from ovine ovarian tissue previously cryopreserved in DMSO grew to antral size in vitro [9]. Development of mature antral follicles in previously frozen marmoset ovarian tissue was observed after grafting [13]. In mice, live births were obtained after autologous [5] and heterologous [6] transplant of cryopreserved ovaries. Furthermore, isolated mouse primary follicles cryopreserved in DMSO were able to undergo folliculogenesis in the absence of other ovarian tissue, and some of the oocytes developed into live young after IVM, IVF and embryo transfer [22].

Paynter et al. [10] reported that bovine ovarian tissue cryopreserved with DMSO retained a reasonable yield of morphologically intact follicles (11-25\%), and that a short period of post-thaw culture may enhance follicle recovery (27-40\%). The percentage of morphologically normal follicles after freeze/thawing observed by Paynter et al. [10] apparently differs greatly from our results (73.9\% in $1.5 \mathrm{M} \mathrm{DMSO}$ ), even though the criteria for classification were similar. However, the percentage of normal follicles in fresh, control ovaries 
also seemed dramatically lower in their work compared to the present study (57\% versus $97 \%$, respectively). It is important to note that we used zebu (Bos indicus) ovaries, while Paynter et al. [10] probably used ovaries from European bovines (Bos taurus); that may be the explanation for these differences. Similarly high percentages of morphologically normal preantral follicles were previously reported in fresh ovaries of zebu cattle (96\% [23]) and other species such as goats (95\% [24]), sheep (98-99\% [25] and [26]), mice (91-99\% [4]), and humans (73\% [11]).

Using $3 \mathrm{M}$ DMSO or either concentration of $\mathrm{PROH}$, ultrastructural evaluation revealed loss of cytoplasm content in some granulosa cells of cryopreserved follicles, but the oocytes per se displayed normal ultrastructure. Slight damage to some granulosa cells is probably not as serious as damage to the oocyte. As granulosa cells proliferate during follicular development, it may be possible for a follicle to sustain the loss of one or two granulosa cells.

In conclusion, DMSO and PROH were the most effective cryoprotectants for zebu ovarian tissue cryostorage, preserving the structural integrity of somatic and reproductive cells within the ovary. The results presented here are promising and may be of great value to safeguard the reproductive potential of economically valuable zebu cows or even endangered bovine breeds. Of course, much effort has yet to be devoted to the growth and maturation of small follicles in vitro before the potential of cryopreservation of ovarian tissue can be fully realized.

\section{Acknowledgements}

This research was partially sponsored by CNPq. We thank J.W. Carmichael for the English correction of the manuscript. We are also grateful to the Laboratório de Morfologia e Morfogênese of University of Brasília, Brazil.

\section{References}

[1] Oktay K, Newton H, Aubard Y, Salha O, Gosden RG. Cryopreservation of immature human oocytes and ovarian tissue: an emerging technology? Fertil Steril 1998;69:1-7.

[2] Gosden RG. Low temperature storage and grafting of human ovarian tissue. Mol Cell Endocr 2000;163:125-9.

[3] Shaw JM, Oranratnachai A, Trounson AO. Fundamental cryobiology of mammalian oocytes and ovarian tissue. Theriogenology 2000;53:59-72.

[4] Candy CJ, Wood MJ, Whittingham DG. Effect of cryoprotectants on the survival of follicles in frozen mouse ovaries. J Reprod Fertil 1997;110:11-9. 
[5] Gunasena KT, Villines PM, Crister ES, Crister JK. Live births after autologous transplant of cryopreserved mouse ovaries. Hum Reprod 1997;12:101-6.

[6] Gunasena KT, Lakey JRT, Villines PM, Crister ES, Crister JK. Allogenic and xenogenic transplantation of cryopreserved ovarian tissue to athymic mice. Biol Reprod 1997;57:226-31.

[7] Gosden RG, Baird DT, Wade JC, Webb R. Restoration of fertility to oophorectomized sheep by ovarian autografts stored at 196 8C. Hum Reprod 1994;9:597-603.

[8] Salle B, Lornage J, Franck M, Isoard L, Rudigoz RC, Guerin JF. Freezing, thawing, and autograft of ovarian fragments in sheep: preliminary experiments and histologic assessment. Fertil Steril 1998;70: 124-8.

[9] Newton H, Picton H, Gosden RG. In vitro growth of oocyte-granulosa cell complexes isolated from cryopreserved ovine tissue. J Reprod Fertil 1999;115:141-50.

[10] Paynter SJ, Cooper A, Fuller BJ, Shaw RW. Cryopreservation of bovine ovarian tissue: structural normality of follicles after thawing and culture in vitro. Cryobiology 1999;38:301-9.

[11] Hovatta O, Silye R, Krausz T, Abir R, Margara R, Trew G, et al. Cryopreservation of human ovarian tissue using dimethylsulphoxide and propanediol-sucrose as cryoprotectants. Hum Reprod 1996;11:1268-72.

[12] Newton H, Aubard Y, Rutherford A, Sharma V, Gosden R. Low temperature storage and grafting of human ovarian tissue. Hum Reprod 1996;11:1487-91.

[13] Candy CJ, Wood MJ, Whittingham DG. Follicular development in cryopreserved marmoset ovarian tissue after transplantation. Hum Reprod 1995;10:2334-8.

[14] Schellander K, Peli J, Schmoll F, Brem G. Effects of different cryprotetants and carbohydrates on freezing of matured and unmatured bovine oocytes. Theriogenology 1994;42:909-15.

[15] Cocero MJ, Lopez-Sebastian A, Barragan ML, Picazo RA. Differences on post-thawing survival between ovine morula and blastocysts cryopreserved with ethylene glycol and glycerol. Cryobiology 1996;33: 502-7.

[16] Chi HJ, Koo JJ, Kim MY, Joo JY, Changs SS, Chung KS. Cryopreservation of human embryos using ethylene glycol in controlled slow freezing. Hum Reprod 2002;17:2146-51.

[17] Sommerfeld V, Noemann H. Cryopreservation of bovine in vitro produced embryos using ethylene glycol in controlled freezing or vitrification. Cryobiology 1999;38:95-105.

[18] Visintin JA, Martins JFP, Bevilacqua EM, Mello MRB, Nica'cio AC. Assumpção MEOA. Cryopreservation of Bos taurus vs. Bos indicus embryos: are they really different? Theriogenology 2002;57:345-59.

[19] Niemmann H. Cryopreservation of ova and embryos from livestock: current status and research needs. Theriogenology 1991;35:109-23. 
[20] Newton H, Fisher J, Arnold JR, Pegg DE, Faddy MJ, Gosden RG. Permeation of human ovarian tissue with cryoprotective agents in preparation for cryopreservation. Hum Reprod 1998;13:376-80.

[21] Cocero MJ, Moreno D'iaz de la Espina S, Aguilar B. Ultrastructural characteristics of fresh and frozen-thawed ovine embryos using two cryoprotectants. Biol Reprod 2002;66:1244-58.

[22] Carroll J, Whittingham DG, Wood MJ, Telfer E, Gosden RG. Extra-ovarian production of mature viable mouse oocytes from frozen primary follicles. J Reprod Fertil 1990;90:321-7.

[23] Lucci CM, Rumpf R, Figueiredo, Bao SN. Zebu (Bos indicus) ovarian preantral follicles: morphological characterization and development of an efficient isolation method.

Theriogenology 2002;57:1467-83.

[24] Lucci CM, Amorim CA, Rodrigues APR, Figueiredo JR, Ba'o SN, Silva JR, et al. Study of preantral follicular population in situ and after mechanical isolation from undefined breed type goats at different reproductive stages. Anim Reprod Sci 1999;56:223-36.

[25] Amorim CA, Lucci CM, Rodrigues APR, Carvalho FCA, Figueiredo JR, Rondina D, et al. Quantitative and qualitative analysis of the effectiveness of a mechanical method for the isolation of preantral follicles from ovine ovaries. Theriogenology 2000;53:1251-62.

[26] Jorio A, Mariana JC, Lahlou-Kassi A. Development of the population of ovarian follicles during the prepubertal period in D'man and Timahdite sheep. Anim Reprod Sci 1991;26:23950 . 